\title{
A study on the biomass variation of the macrophytes in Poiroupat Lake, Manipur, northeast India
}

\author{
${ }^{*}$ K. Khelchandra Singh ${ }^{1}$, Khuraijam Usha ${ }^{2}$, B. M. Sharma ${ }^{3}$ \\ IDepartment of Environmental Science, Pachhunga University College, Aizawl 7960or, Mizoram \\ ${ }^{2}$ Department of Environmental Science, D.M. College of Science, Imphal 79500I, Manipur \\ ${ }^{3}$ Ecology Research Laboratory, Centre of Advanced Study, Department of Life Sciences, Manipur University, Imphal 795003, \\ Manipur
}

\begin{abstract}
Biomass assessment of the macrophytic plant species were carried out at Poiroupat lake located in Imphal East district of Manipur. The present study reveals the presence of 30 aquatic macrophytes. The recorded aquatic macrophytes of the lake have been classified into four categories, viz. submerged (10\%), rooted with floating leaves (16.7\%), free floating (20\%) and emergent (53.3\%). In all the study sites, Ceratophyllum demersum recorded the maximum total biomass with values ranging from 24.52 (Site I) to $241.45 \mathrm{gm}^{-2}$ (Site III). This was followed by Alternanthera philoxeroides with values ranging from 25.74 (Site II) to $139.77 \mathrm{gm}^{-2}$ (Site II). This was successively followed by Utricularia flexuosa (14.12 to $110.45 \mathrm{gm}^{-2}$ ), Ludwigia adscendens (14.09 to $89.32 \mathrm{gm}^{-2}$ ), Nymphaea stellata (29.66 to $84.32 \mathrm{gm}^{-2}$ ), Nelumbo nucifera (15.03 to $67.41 \mathrm{gm}^{-2}$ ), Hydrilla verticillata (16.09 to $67.00 \mathrm{gm}^{-2}$ ), Hygroryza aristata (30.95 to $62.52 \mathrm{gm}^{-2}$ ), Ipomoea aquatica (4.54 to $58.31 \mathrm{gm}^{-2}$ ), Nymphoides indicum (4.41 to $47.95 \mathrm{gm}^{-2}$ ). Eichhornia crassipes recorded peak value of $26.54 \mathrm{gm}^{-2}$. During the entire study period, the total biomass of all species (combined) ranged from 130.07 to 512.28 $\mathrm{gm}^{-2}$. The maximum biomass values were recorded during rainy season.
\end{abstract}

Key words: Biomass, Macrophytes, Poiroupat, Lake, Manipur.

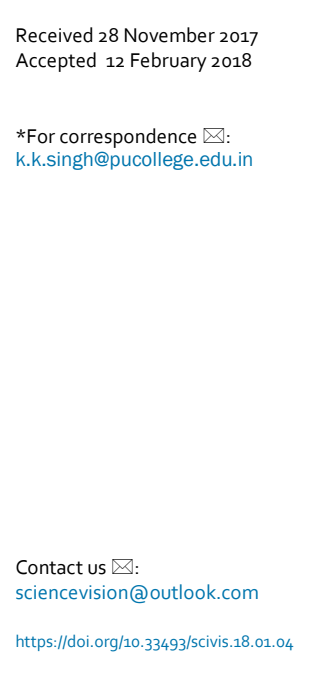

Received 28 November 2017

*For correspondence $\otimes$ : k.k.singh@pucollege.edu.in

\section{Introduction}

Biomass is usually expressed as living weight, dry weight, ash-free dry weight or carbon weight or calories or any other convenient unit for comparative purposes and is also expressed as the 'organism mass' in unit area. ${ }^{1}$ Biomass is the total amount of Organic matter present at a given time per unit area of the earth's surface. ${ }^{2}$ The biomass is an expression of the standing crop which is referred to as the amount of living materials in a trophic level or component population. Biomass determination is one of the most important tools for evaluation of the primary productivity. Species which accumulate more biomass and having higher production rates are found dominant in the community and hence they usually influence the overall physiognomy of the vegetation. ${ }^{3}$

Studies on the variation of biomass of the macrophytes of freshwater ecosystems in India and abroad were undertaken various researchers viz., Gopal et al., ${ }^{4}$ Billore \& Vyas, ${ }^{5}$ Yadava et 
al., ${ }^{6}$ Shardendu \& Ambasht, ${ }^{7}$ Devi, ${ }^{8-14}$ Zotina, ${ }^{15}$ Singh et. al., ${ }^{16}$ Devi, ${ }^{17-18}$ Singh \& Sharma, ${ }^{19}$ Maqbool \& Khan, ${ }^{20}$ Tamire \& Mengistou, ${ }^{21}$ etc. The present study has been undertaken to determine the biomass variation of the aquatic macrophytes found in the lake under study. This study would supplement the existing database on variation in the biomass of the aquatic macrophytes in freshwater ecosystems of the state.

\section{Materials and Methods}

Poiroupat is situated in the Imphal East district of Manipur at a distance of $15 \mathrm{~km}$ from the Imphal city. It lies between $24^{\circ} 406.24 \mathrm{~N}$ to $24^{\circ} 40$ '6.71 N latitude and $93^{\circ} 589.82$ E to $93^{\circ} 5810.25$ longitude. The lake is about $881 \mathrm{~m}$ above mean sea level with an area of $0.16 \mathrm{sq} . \mathrm{km}$. It is a much aged, and eutrophic and it is one of the endangered lakes of Manipur. Rain and ground water are the only source of water to this lake. At present, the lake is threatened to extinction due to artificial eutrophication which is attributed to encroachment and pisciculture.
For the present study, the lake was divided into four sites representing as site I, II, III and IV which were named as Sabam, Kabui Panung, Thambou Kom and Thaba Konjin respectively (Fig. 1). Site I - Sabam: This site has an area of $0.02 \mathrm{sq} \mathrm{km}$ and water depth ranged from 82.4 to $186.0 \mathrm{~cm}$ during the whole study period. 18 macrophytes were recorded in this site in the different seasons. Site II - Kabui Panung: This site is just adjacent to site I with an area of 0.06 $\mathrm{sq} \mathrm{km}$. The depth of the water ranged from 85.4 to $190.0 \mathrm{~cm}$. In this site 17 macrophytes were found during the study period. Site III - Thambou Kom: This is the largest site with an area of $0.07 \mathrm{sq} . \mathrm{km}$ and depth of water ranged from 82.5 to $192.0 \mathrm{~cm}$ during the whole study period. Maximum number of macrophytes (21 species) was recorded in this site in the different seasons. Site IV - Thaba konjin: This is the smallest site of the lake. It has an area of $0.01 \mathrm{sq}$. $\mathrm{km}$. The depth of the water during the whole study period ranged from 79.0 to $172.3 \mathrm{~cm}$. Here 17 macrophytes were recorded during the study period.

The macrophytic plant samples were collected from each site on monthly basis during

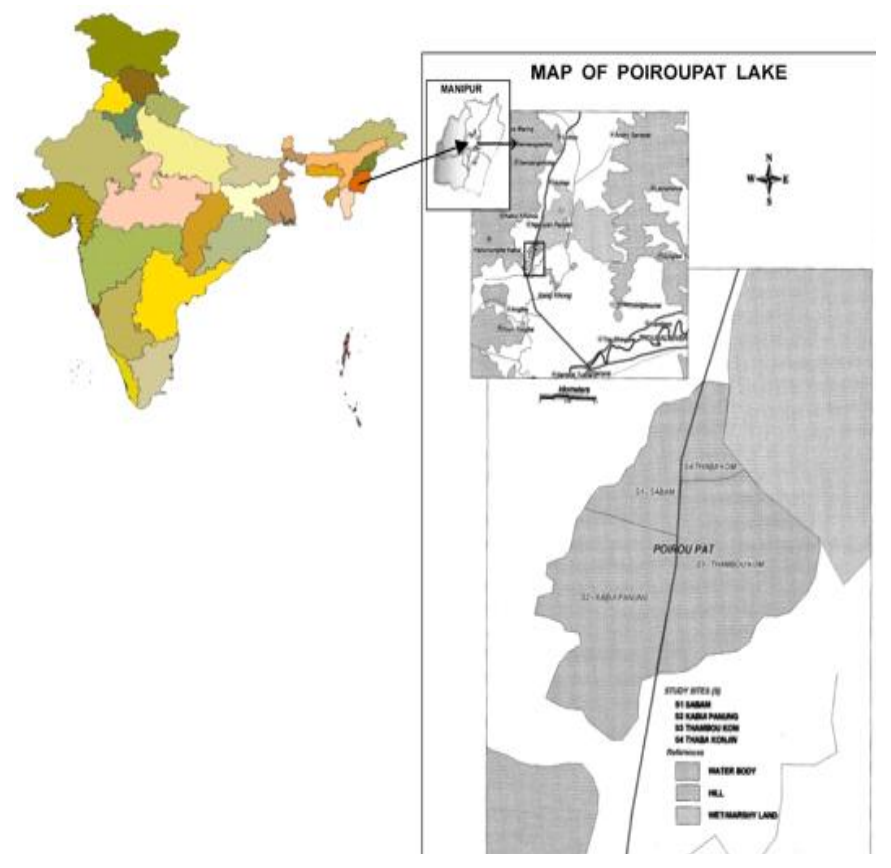

Figure 1 | Location map of the study site. 
June 2010 to May 2012. Standing crop biomass was estimated by Harvest method ${ }^{22}$. Macrophytic plants were sampled on monthly basis during the study. Plant samples were collected using quadrats of $25 \times 25 \mathrm{~cm}$ in dimension from the vertical core sampling sites and the cumulative data were analyzed. However, for the sampling of some submerged species methods described by Ekman Dredge ${ }^{23}$ were used. After collection each sample was kept in polythene bags marked with wax pencil and brought to the laboratory. Plant materials were washed to remove the adhering silt, soil, mud, other plants and animal debris etc. Then the plants were sorted out as dominant species and remaining as 'other species'. Excess of water was drained using blotting papers. Fresh weights of the different species were taken by differentiating into shoot and root portions. The root portions of the submerged species are generally found to be insignificant and as such the same may be neglected $^{24}$. After taking the fresh weights, each labeled sample packed in paper bags was dried in the oven at $80^{\circ} \mathrm{C}$ for 48 hours. Later, dry weights of the shoot and root portions were taken separately. Thus, biomass of the macrophytes were calculated on dry weight basis and expressed in grams per square metre $\left(\mathrm{gm}^{-2}\right)$.

\section{Results}

The present study revealed the presence of 30 aquatic macrophytes. Generally, the vegetation of Poiroupat Lake has been classified into four classes viz. (i) Submerged (10\%) (ii) Rooted with floating leaves (16.7\%) (iii) Free floating (20\%) and (iv) Emergent (53.3\%). The ranges and mean biomass value in the different study sites of Poiroupat lake, Manipur are furnished in $\mathrm{Ta}$ ble 1, 2 and 3. The higher ranges of biomass are recorded in Alternanthera philoxeroides, Ceratophyllum demersum, Hydrilla verticillata, Ludwigia adscendens, Nymphaea stellata, Utricularia flexuosa etc. Among the dominant species Ceratophyllum demersum recorded peak value of biomass values in Sites II \& III.

The biomass values of $\mathrm{C}$. demersum varied from 29.01 to $218.30 \mathrm{gm}^{-2}$ in the first year and 24.52 to $241.45 \mathrm{gm}^{-2}$ in the second year (Fig. 2 \& 3). C. demersum recorded a mean biomass value of $112.82 \pm 47.72 \mathrm{gm}^{-2}$. The biomass value of $A$. philoxeroides ranged from 25.74 to $139.77 \mathrm{gm}^{-2}$ in the first year and 38.13 to $120.84 \mathrm{gm}^{-2}$ in the second year with a mean biomass value of $69.86 \pm$ $20.08 \mathrm{gm}^{-2}$ during the entire study period. $U$. flexuosa recorded biomass values of 14.12 to $110.45 \mathrm{gm}^{-2}$ and 24.25 to $94.25 \mathrm{gm}^{-2}$ in the first

Table 1 | Ranges and mean biomass values $\left(\mathrm{gm}^{-2}\right)$ in different sites of Poiroupat Lake during the first year of study.

\begin{tabular}{|c|c|c|c|c|c|c|}
\hline Name of Species & $\begin{array}{c}\text { Range } \\
\text { (entire lake) }\end{array}$ & Site-I & Site-II & Site-III & Site-IV & Mean \pm SD \\
\hline Alternanthera philoxeroides & $25.74-139.77$ & 104.96 & 50.96 & 60.43 & 66.44 & $70.70 \pm 23.72$ \\
\hline Ceratophyllum demersum & 29.01- 218.0 & 57.73 & 158.15 & 147.76 & 92.27 & $113.98 \pm 47.36$ \\
\hline Eichhornia crassipes & $6.90-26.54$ & 10.53 & 16.72 & 7.52 & 11.86 & $11.66 \pm 3.83$ \\
\hline Hydrilla verticillata & $16.09-55.44$ & 35.76 & 41.97 & 49.37 & 23.72 & $37.71 \pm 10.86$ \\
\hline Hygroryza aristata & $32.23-60.52$ & 46.36 & 25.03 & 18.26 & 19.52 & $27.29 \pm 13.05$ \\
\hline Ipomoea aquatica & $4.54-48.37$ & 12.98 & 15.85 & 17.6 & 33.84 & $20.07 \pm 9.38$ \\
\hline Ludwigia adscendens & $14.05-68.77$ & 53.10 & 23.58 & 36.27 & 12.52 & $31.37 \pm 17.44$ \\
\hline Nelumbo nucifera & $15.03-59.41$ & 40.56 & 25.53 & 56.39 & 44.63 & $41.78 \pm 12.74$ \\
\hline Nymphoides indicum & $8.79-40.68$ & 25.78 & 24.73 & 14.23 & 25.14 & $22.47 \pm 5.51$ \\
\hline Nymphaea stellata & $29.66-75.12$ & 44.52 & 20.05 & 52.39 & 24.82 & $35.45 \pm 15.49$ \\
\hline Salvinia cucullata & $16.02-30.93$ & 18.74 & 23.47 & 19.56 & 20.89 & $20.67 \pm 2.07$ \\
\hline Utricularia flexuosa & $14.12-110.45$ & 35.86 & 49.64 & 53.46 & 70.39 & $52.34 \pm 14.21$ \\
\hline Other Species & $8.48-31.28$ & 22.87 & 16.99 & 14.90 & 20.73 & $18.88 \pm 3.60$ \\
\hline All Species (Combined) & $154.55-512.03$ & 307.39 & 308.29 & 340.19 & 328.22 & $321.03 \pm 15.99$ \\
\hline
\end{tabular}


Table 2 | Ranges and mean biomass values $\left(\mathrm{gm}^{-2}\right)$ in different sites of Poiroupat Lake during the second year of study.

\begin{tabular}{|c|c|c|c|c|c|c|}
\hline Name of Species & $\begin{array}{c}\text { Range } \\
\text { (entire lake) }\end{array}$ & Site-I & Site-II & Site-III & Site -IV & Mean \pm SD \\
\hline Alternanthera philoxeroides & $38.13-120.84$ & 92.58 & 55.43 & 60.57 & 67.51 & $69.02 \pm 16.47$ \\
\hline Ceratophyllum demersum & $24.52-241.45$ & 81.66 & 151.20 & 159.38 & 54.39 & $111.66 \pm 51.71$ \\
\hline Eichhornia crassipes & $8.16-22.75$ & 9.52 & 15.45 & 18.21 & 12.65 & $13.96 \pm 3.73$ \\
\hline Hydrilla verticillata & $22.33-67.00$ & 35.82 & 46.73 & 37.52 & 52.37 & $43.11 \pm 7.81$ \\
\hline Hygroryza aristata & $30.95-62.52$ & 46.73 & 39.52 & 29.87 & 35.75 & $37.97 \pm 7.07$ \\
\hline Ipomoea aquatica & $28.54-58.31$ & 42.85 & 38.12 & 43.42 & 39.20 & $40.90 \pm 2.63$ \\
\hline Ludwigia adscendens & $37.11-89.32$ & 65.04 & 43.38 & 61.76 & 26.94 & $49.28 \pm 17.68$ \\
\hline Nelumbo nucifera & $15.33-67.41$ & 39.43 & 36.65 & 29.65 & 49.82 & $38.89 \pm 8.37$ \\
\hline Nymphoides indicum & $4.41-47.95$ & 23.65 & 32.45 & 20.54 & 18.76 & $23.85 \pm 6.08$ \\
\hline Nymphaea stellata & $37.37-84.32$ & 52.63 & 50.64 & 60.84 & 44.6 & $52.18 \pm 6.71$ \\
\hline Salvinia cucullata & $14.36-34.12$ & 21.54 & 24.24 & 20.65 & 19.36 & $21.45 \pm 2.07$ \\
\hline Utricularia flexuosa & $24.25-94.25$ & 58.61 & 65.23 & 78.73 & 52.83 & $63.85 \pm 11.14$ \\
\hline Other Species & $8.79-48.23$ & 18.87 & 23.36 & 23.41 & 28.51 & $23.54 \pm 3.94$ \\
\hline All Species (Combined) & $130.07-512.28$ & 319.71 & 330.56 & 343.95 & 324.81 & $333.64 \pm 13.33$ \\
\hline
\end{tabular}

Table 3 | Ranges and mean biomass values $\left(\mathrm{gm}^{-2}\right)$ in different sites of Poiroupat Lake during the entire study.

\begin{tabular}{lccccc}
\hline \multicolumn{1}{c}{ Name of Species } & Site-I & Site-II & Site-III & Site-IV & Mean \pm SD \\
\hline Alternanthera philoxeroides & 98.77 & 53.20 & 60.50 & 66.98 & $69.86 \pm 20.08$ \\
\hline Ceratophyllum demersum & 69.70 & 154.68 & 153.57 & 73.33 & $112.82 \pm 47.72$ \\
\hline Eichhornia crassipes & 10.03 & 16.09 & 12.87 & 12.26 & $12.81 \pm 2.50$ \\
\hline Hydrilla verticillata & 35.79 & 44.35 & 43.45 & 38.05 & $40.41 \pm 4.15$ \\
\hline Hygroryza aristata & 46.55 & 32.28 & 24.07 & 27.64 & $32.63 \pm 9.87$ \\
\hline Ipomoea aquatica & 27.92 & 26.99 & 30.51 & 36.53 & $30.48 \pm 4.29$ \\
\hline Ludwigia adscendens & 59.07 & 33.48 & 49.02 & 19.73 & $40.32 \pm 17.30$ \\
\hline Nelumbo nucifera & 40.00 & 31.10 & 43.02 & 47.23 & $40.33 \pm 6.84$ \\
\hline Nymphoides indicum & 24.72 & 28.60 & 17.39 & 21.95 & $23.16 \pm 4.72$ \\
\hline Nymphaea stellata & 48.58 & 35.35 & 56.62 & 34.71 & $43.81 \pm 10.66$ \\
\hline Salvinia cucullata & 20.14 & 23.86 & 20.11 & 20.13 & $21.06 \pm 1.87$ \\
\hline Utricularia flexuosa & 47.24 & 57.44 & 66.10 & 61.61 & $58.10 \pm 8.06$ \\
\hline Other Species & 20.87 & 20.18 & 19.16 & 24.62 & $21.21 \pm 2.38$ \\
\hline All Species (Combined) & 313.55 & 319.43 & 342.08 & 326.52 & $325.39 \pm 12.32$ \\
\hline
\end{tabular}

and second year of the study period. The maximum value was reported from study Site IV. The mean value for $U$. flexuosa during the study period is $58.10 \pm 8.06 \mathrm{gm}^{-2}$. L. adscendens had biomass values ranging from 14.09 to $68.77 \mathrm{gm}^{-2}$ in the first year and 37.11 to $89.32 \mathrm{gm}^{-2}$ in the second year with mean value of $40.32 \pm 17.30 \mathrm{gm}^{-2}$. The biomass value of $N$. stellata ranged from 29.66 to $75.12 \mathrm{gm}^{-2}$ in the first year and 37.37 to $84.32 \mathrm{gm}^{-2}$ in the second year. The biomass values of Nelumbo nucifera varied from 15.03 to 59.41 $\mathrm{gm}^{-2}$ in the first year and 15.33 to $67.41 \mathrm{gm}^{-2}$ in the second year with mean value of $40.33 \pm 6.84$ $\mathrm{gm}^{-2}$. The peak biomass values were recorded during rainy season (July and August) while the lowest values were observed during winter season (December) in the consecutive years of study period.

$H$. verticillata had biomass values ranging from 16.09 to $55.44 \mathrm{gm}^{-2}$ in the first year and 22.33 to $67.00 \mathrm{gm}^{-2}$ in the second year. H. verticillata recorded mean biomass value of $40.10 \pm 4.15$ 
Table 4 | Comparison of biomass values of the aquatic macrophytes in different freshwater ecosystems.

\begin{tabular}{|c|c|c|}
\hline Ecosystem & Biomass $\left(\mathrm{gm}^{-2}\right)$ & Authors \\
\hline Poiroupat lake, Manipur & $\begin{array}{l}154.55-512.03\left(1^{\text {st }} \text { Year }\right) \\
130.07-512.28\left(2^{\text {nd }} \text { Year }\right)\end{array}$ & Present Study \\
\hline Osby lake, Sweden & 520.00 & Forsberg 40 \\
\hline Freshwater ponds, Varanasi & $1,250.00$ & Ambasht $^{31}$ \\
\hline Wetlands, Malaysia & $370.00-520.00$ & Wassink $^{36}$ \\
\hline Opinicon lake, Canada & 1154.00 & Crowder et al., ${ }^{32}$ \\
\hline Manasbal and Anchar lake, Kashmir & 970.00 and 1010.00 & Kaul $^{33}$ \\
\hline Ramgarh Reservoir & $92.90-564.50$ & Gopal et al., ${ }^{4}$ \\
\hline Pichhola lake, Udaipur & $10.00-35.80$ & Billore \& Vyas ${ }^{37}$ \\
\hline Lakes of Udaipur & $537.60-1884.09$ & Vyas et al. ${ }^{35}$ \\
\hline Eutrophic ponds, Michigan & $196.00-260.00$ & Spencer \& King ${ }^{38} ;$ Freeman $^{39}$ \\
\hline Waikaremona lake, New Zealand & 1106.00 & Howard-Williams et al. ${ }^{34}$ \\
\hline Shallow ponds, Varanasi & 778.00 & Misra $^{3}$ \\
\hline Loktak lake, Manipur & $363.21-782.63$ & Devi $^{8}$ \\
\hline Waithou lake, Manipur & $422.97-1305.70$ & Devi ${ }^{29}$ \\
\hline Utrapat lake, Manipur & $139.18-579.85$ & Devi $^{9}$ \\
\hline Freshwater Ecosystems, Canchipur, Manipur & $55.13-408.40$ & Devi $^{10}$ \\
\hline Deux Montagnes lake, Canada & 112.20 & Hudon et al. ${ }^{43}$ \\
\hline Sanapat lake, Manipur & $33.19-229.53$ & Devi $^{11}$ \\
\hline Ikop lake, Manipur & $16.81-295.62$ & Devi \& Sharma ${ }^{44}$ \\
\hline Awangsoipat lake, Manipur & $164.45-841.00$ & Devi $^{13}$ \\
\hline Oksoipat lake, Manipur & $150.87-588.05$ & Devi \& Sharma ${ }^{27}$ \\
\hline Kharungpat lake, Manipur & $304.01-989.95$ & Singh et al. ${ }^{16}$ \\
\hline Hidenkompat lake, Manipur & $292.67-855.78$ & Devi 18 \\
\hline Yenapat lake, Manipur & $198.80-866.40$ & Devi ${ }^{17}$ \\
\hline
\end{tabular}

$\mathrm{gm}^{-2}$. Hygroryza aristata had biomass values ranging from 32.23 to $60.52 \mathrm{gm}^{-2}$ in the first year and 30.95 to $62.52 \mathrm{gm}^{-2}$ in the second year. During the whole study period the biomass value of Ipomoea aquatica varied from 4.54 to $48.37 \mathrm{gm}^{-2}$ in the first year and 28.54 to $58.31 \mathrm{gm}^{-}$ 2 in the second year. The biomass values of Nymphoides indicum varied from 8.79 to $40.68 \mathrm{gm}^{-2}$ in the first year and 4.41 to $47.95 \mathrm{gm}^{-2}$ in the second year and that of Eichhornia crassipes from 6.90 to $26.54 \mathrm{gm}^{-2}$ and 8.16 to $22.75 \mathrm{gm}^{-2}$ in the first year and second year respectively.

The biomass values of Salvinia cucullata ranged from 16.02 to $30.93 \mathrm{gm}^{-2}$ in the first year and 14.36 to $34.12 \mathrm{gm}^{-2}$ in the second year. The biomass values of other species ranged from 8.48 to $31.28 \mathrm{gm}^{-2}$ in the first year and 8.79 to $48.23 \mathrm{gm}^{-2}$ in the second year. During the whole study period, the total biomass of all species (combined) in the different study sites ranged from 154.55 to $512.03 \mathrm{gm}^{-2}$ and 130.07 to 512.28 $\mathrm{gm}^{-2}$ in the first year and second year respectively (Fig. 4). The mean biomass values of all species (combined) during the entire study period is $325.39 \pm 12.32 \mathrm{gm}^{-2}$.

\section{Discussion}

In the present study the recorded biomass values of Ceratophyllum demersum are slightly higher when compared with those reported by Sahai \& Sinha ${ }^{25}$ from Gorakhpur (161.00 $\mathrm{gm}^{-2}$ ), Shah \& Abbas ${ }^{26}$ in Bhagalpur (90.60 to $135.60 \mathrm{gm}^{-}$ $\left.{ }^{2}\right)$ and Singh et al. ${ }^{16}$ in Kharungpat lake, Manipur with values varying from 34.65 to $128.22 \mathrm{gm}^{-2}$ in the first year and 42.54 to $155.82 \mathrm{gm}^{-2}$ in the second year. Devi ${ }^{13}$ in Awangsoipat Lake, Manipur reported biomass values ranging from 20.14 to $163.56 \mathrm{gm}^{-2}$ in the first year and 39.56 to 175.32 $\mathrm{gm}^{-2}$ in the second year which are lower when 


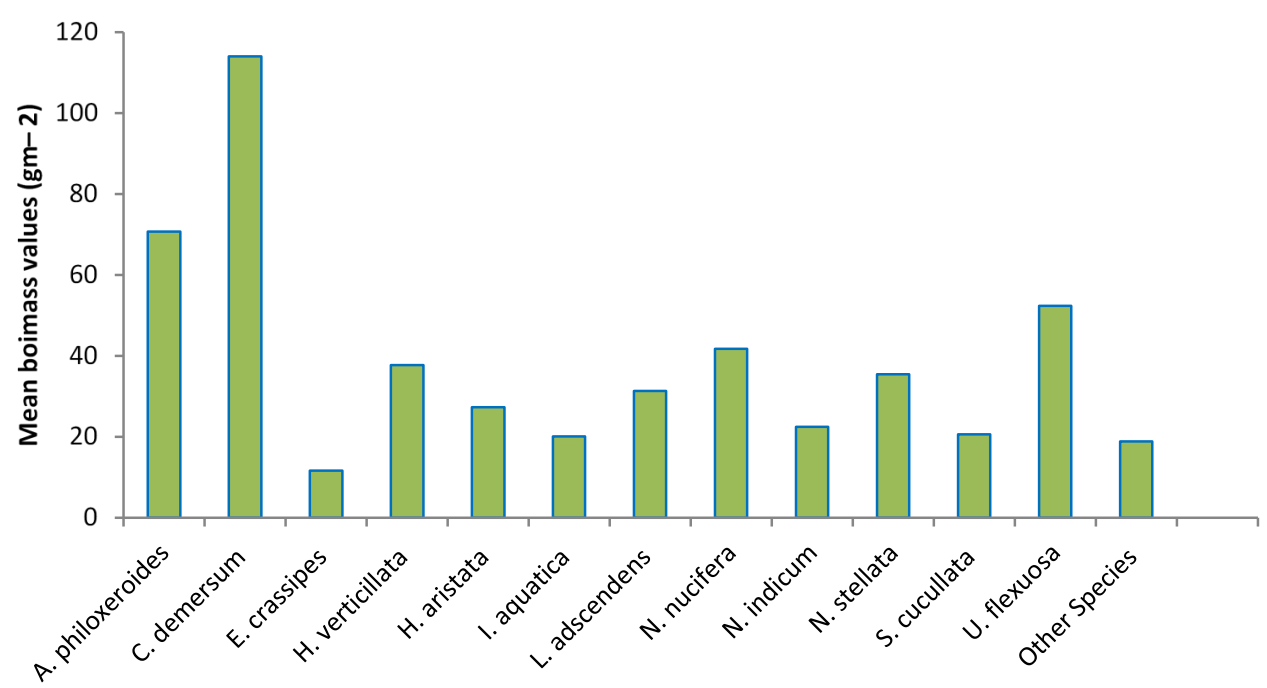

Figure 2 | Biomass variation of aquatic macrophytes in first year of study period.

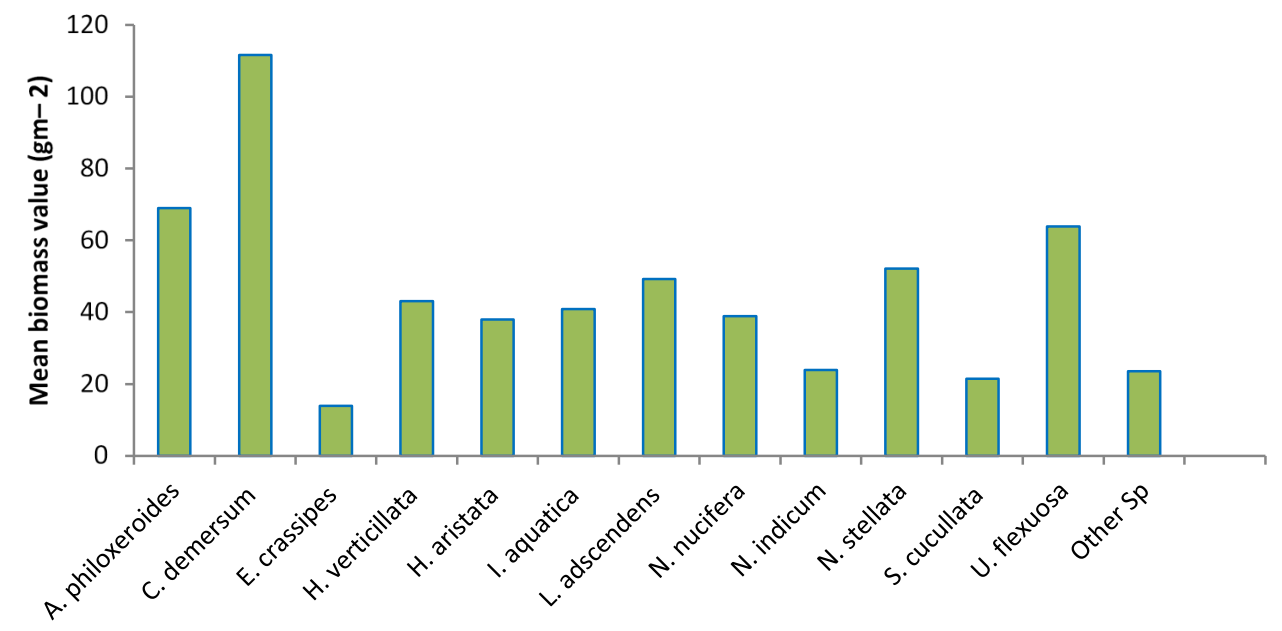

Figure 3 | Biomass variation of aquatic macrophytes in second year of study period.

compared with the present findings. Devi \& Sharma $^{27}$ in Oksoipat Lake, Manipur also reported lower values varying from 46.88 to 155.63 $\mathrm{gm}^{-2}$ in the first year and 30.53 to $168.96 \mathrm{gm}^{-2}$ in the second year. Devi ${ }^{18}$ recorded lower values in Hidenkompat lake, Manipur (22.80 to $164.90 \mathrm{gm}^{-}$ $\left.{ }^{2}\right)$, Sharma \& Devi ${ }^{28}$ in Loktak lake, Manipur reported comparable values of biomass (9.23 to $214.01 \mathrm{gm}^{-2}$.

The biomass values of Alternanthera philoxer- oides observed in the present study are comparatively higher than those reported by various authors viz., Devi ${ }^{29}$ in Waithou lake, Manipur (53.70 $\mathrm{gm}^{-2}$ in the first year and $50.30 \mathrm{gm}^{-2}$ in the second year), Devi in Utrapat ${ }^{9}$ lake, Manipur (57.12 to $\left.93.01 \mathrm{gm}^{-2}\right)$ and $\mathrm{Devi}^{17}$ in Yenapat lake, Manipur $\left(73.30 \mathrm{gm}^{-2}\right)$. Biomass values comparable to the present study were reported by Devi in Awangsoipat lake ${ }^{13}$, Manipur (32.55 to $124.35 \mathrm{gm}^{-}$ ${ }^{2}$ in the first year and 22.50 to $153.06 \mathrm{gm}^{-2}$ in the 


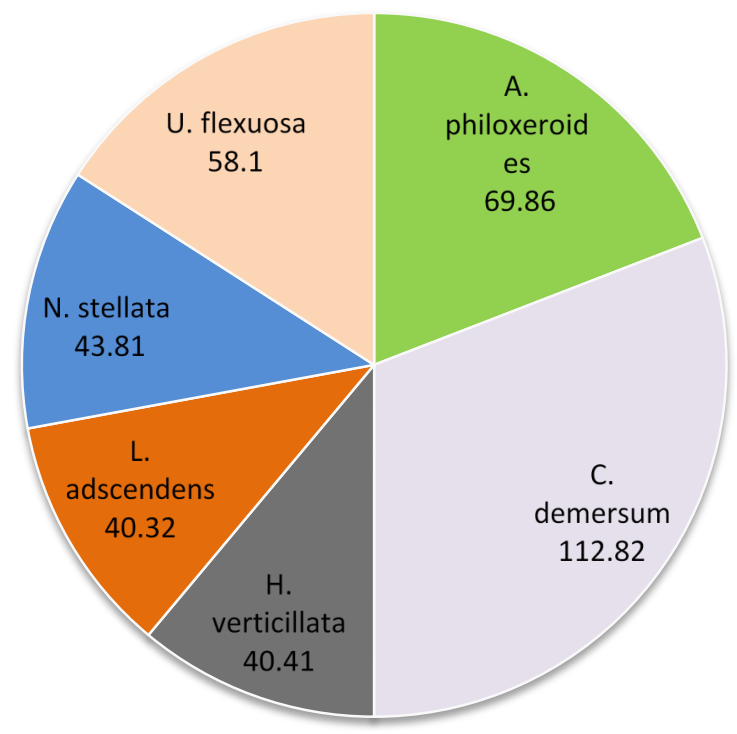

Figure 4 | Biomass values of the dominant aquatic macrophytes during the entire study period $\left(\mathrm{gm}^{-2}\right)$.

second year) and Devi \& Sharma ${ }^{27}$ in Oksoipat lake, Manipur (19.94 to $139.41 \mathrm{gm}^{-2}$ in the first year and 21.44 to $135.79 \mathrm{gm}^{-2}$ in the second year of study). However, the findings are found to be lower when compared with those reported by Singh et al. ${ }^{16}$ in Kharungpat lake, Manipur where the biomass value of $\mathrm{A}$. philoxeroides ranged from 56.41 to $183.48 \mathrm{gm}^{-2}$ in the first year and 53.97 to $201.45 \mathrm{gm}^{-2}$ in the second year.

The biomass values of $L$. adscendens of the present study are found to be in close conformity when compared with the ones reported by Devi $^{13}$ in Awangsoipat lake, Manipur with values ranging from 18.03 to $66.86 \mathrm{gm}^{-2}$ and 10.04 to $52.80 \mathrm{gm}^{-2}$ in the two consecutive years of study. However, the present values of biomass for $\mathrm{L}$. adscendens are found to be lower when compared with those reported in Hidenkompat lake, Manipur (12.52 to $\left.122.86 \mathrm{gm}^{-2}\right) \cdot{ }^{18}$ In the present study, the peak biomass values of $H$. verticillata for the two consecutive years were reported during rainy season (July). In consonance with the present findings, peak biomass value for $\mathrm{H}$. verticillata (443.08 $\mathrm{gm}^{-2}$ ) were also recorded during rainy season (July) from Loktak lake, Manipur. ${ }^{8}$ Similarly, Mishra \& Tripathi ${ }^{30}$ also observed peak biomass values during rainy seasons.

The present findings of biomass values for $\mathrm{H}$. aristata are comparable with those in Oksoipat lake, Manipur with biomass values ranging 17.44 to $64.26 \mathrm{gm}^{-2}$ in the second year. ${ }^{27}$ The biomass value of Ipomoea aquatica are found to be slightly higher when compared with those reported in Sanapat lake ${ }^{11}$, Manipur with values in the range of 4.87 to $26.93 \mathrm{gm}^{-2}$ and in Awangsoipat lake ${ }^{13}$, Manipur with values of 1.33 to $19.69 \mathrm{gm}^{-2}$. The biomass values of Eichhornia crassipes are found to be lower when compared with the one reported in Kharungpat lake ${ }^{16}$, Manipur with biomass values ranging from 13.08 to $72.21 \mathrm{gm}^{-2}$ in the first year and 15.83 to $94.25 \mathrm{gm}^{-2}$ in the second year and in Oksoipat lake ${ }^{27}$, Manipur with biomass values ranging from 17.87 to $64.96 \mathrm{gm}^{-2}$ in the first year and 17.76 to $69.02 \mathrm{gm}^{-2}$ in the second year. The present findings of biomass values for Salvinia cucullata are found to be lower with those reported in Oksoipat lake ${ }^{27}$, Manipur with biomass values varying from 9.17 to 47.46 $\mathrm{gm}^{-2}$ in the first year and 14.99 to $67.52 \mathrm{gm}^{-2}$ in the second year as well as in Kharungpat lake ${ }^{16}$, Manipur with values ranging from 9.06 to 52.20 $\mathrm{gm}^{-2}$ in the first year and 13.37 to $49.73 \mathrm{gm}^{-2}$ in the second year.

A comparative account of the biomass variation of the macrophytes in different Freshwater Ecosystems is presented in Table 4 . The present findings for the total biomass of all species (combined) in the different study sites of the lake are found to be lower than those reported by earlier workers viz., Forsberg ${ }^{40}$ in Osby Lake, Sweden $\left(620 \mathrm{gm}^{-2}\right)$; Ambasht ${ }^{31}$ in Freshwater ponds, Varanasi $\left(1250 \mathrm{gm}^{-2}\right)$; Crowder et al. ${ }^{32}$ in Lake Opinicon, Canada $\left(1154.00 \mathrm{gm}^{-2}\right)$; $\mathrm{Kaul}^{33}$ in Manasbal and Anchar lake, Kashmir observing $970 \mathrm{gm}^{-2}$ and $1010 \mathrm{gm}^{-2}$ respectively; HowardWilliams et al. ${ }^{34}$ in Waikaremona lake, New Zealand (1106 $\mathrm{gm}^{-2}$ ); Vyas et. al. ${ }^{35}$ in five major lakes of Udaipur (537.6 to $1884.09 \mathrm{gm}^{-2}$ ) and $\mathrm{Devi}^{29}$ in Waithou lake, Manipur (422.97 to 1173.01). Devi ${ }^{13}$ in Awangsoipat lake, Manipur (164.45 to 841.00 $\mathrm{gm}^{-2}$ ); Devi in Loktak lake, Manipur (363.21 to $782.63 \mathrm{gm}^{-2}$ ). Singh et al. ${ }^{16}$ in Kharungpat lake, Manipur (304.01 to $989.95 \mathrm{gm}^{-2}$ ), Devi ${ }^{17}$ in Yenapat lake, Manipur (198.80 to $866.40 \mathrm{gm}^{-2}$ ), Devi ${ }^{18}$ 
in Hidenkompat lake, Manipur (292.67 to 855.78 $\mathrm{gm}^{-2}$ ).

The present findings are found to be in close conformity with the those reported by Wassink ${ }^{36}$ in some wetlands in Malaysia (where the biomass ranges from 370.0 to $520.0 \mathrm{gm}^{-2}$ ); Devi in Utrapat lake, Manipur (139.18 to $579.85 \mathrm{gm}^{-2}$ ); Devi $^{10}$ in Freshwater Ecosystems of Canchipur, Manipur (36.09 to $408.40 \mathrm{gm}^{-2}$ ); Devi \& Sharma ${ }^{27}$ in Oksoipat lake, Manipur (150.87 to $588.05 \mathrm{gm}^{-2}$ ). Lower biomass values are reported by Billore \& Vyas $^{37}$ in Pichhola lake, Udaipur (10.0 to $35.80 \mathrm{gm}$ $\left.{ }^{-2}\right)$; Spencer \& King $^{38}$ and Freeman ${ }^{39}$ in Eutrophic ponds, Michigan (196 to $260 \mathrm{gm}^{-2}$ ); Devi ${ }^{12}$ in Ikop lake, Manipur (16.81 to $295.62 \mathrm{gm}^{-2}$ ). The present lake falls within the average global biomass values for the lakes and streams ${ }^{41}$ of the world which varied from 0.02 to $0.1 \mathrm{kgm}^{-2}$. Biomass data for lakes in different parts of the world has also been given by Sculthrope ${ }^{42}$ in which the biomass values ranged from 0.07 to $680 \mathrm{gm}^{-2}$ in temperate lakes, 50 to $1000 \mathrm{gm}^{-2}$ in lakes of New Zealand and 630 to $4640 \mathrm{gm}^{-2}$ in reed swamps of Minnesota (U.S.A).

\section{Conclusion}

The variations in the biomass for the dominant aquatic macrophytes of Poiroupat lake varied considerably during the entire study period. The biomass values were found to be comparable to other lakes of Manipur, as well as other wetlands of India and abroad. The higher values of biomass observed in the different study sites are indicative of the eutrophic status of the lake. There has been constant exploitation of the lake by the people living in the vicinity of the lake. So, it is high time to take up preventive and corrective steps to control the lake from degradation.

\section{Acknowledgements}

The authors are thankful to the Head, Department of Life Sciences, Manipur University, Canchipur, Imphal for providing various facilities to carry out the present work.

\section{References}

I. Odum, E.P. (1971). Fundamentals of Ecology. Third Edition. W.B. Saunders Co., Philadelphia, pp. I-574.

2. Whittaker, R.H. (1975). Communities and Ecosystems. Second Edition. Macmillan \& Co., New York, pp. I-352.

3. Misra, K.C. (1989). Manual of Plant Ecology. Third Edition, Oxford \& IBH, New Delhi, pp. I-49I.

4. Gopal, B., Sharma, K.P. \& Trivedy, R.K. (1978). Studies on Ecology and Production in Indian Freshwater Ecosystems at Primary Producer level with emphasis on macrophytes. In: Glimpses of Ecology. (J.S. Singh \& B. Gopal, eds.), International Scientific Publications Jaipur, India, pp. 349-376.

5. Billore, D.K. \& Vyas, L.N. (I98I). Distribution and production of macrophytes in Pichhola lake, Udaipur (India). International Journal of Ecology and Environmental Science 7, 45-54.

6. Yadava, Y.S., Singh, R.K., Choudhury, M. \& Kolekar, V. (1987). Limnology and Productivity of Dighali Beel (Assam). Tropical Ecology 28, 137-747.

7. Shardendu \& Ambasht, R.S. (199I). Relationship of nutrients in water with biomass and nutrients accumulation of submerged macrophytes of a tropical wetland. New Phytologist II7, 493-500.

8. Devi, N.B. (1993). Phytosociology, primary production and nutrient status of macrophytes of Loktak lake, Manipur. Ph.D. Thesis, Manipur University, Manipur, India.

9. Devi, K.I. (1998). Ecological studies of Freshwater macrophytes in Utrapat lake, Manipur. Ph.D. Thesis, Manipur University, Manipur, India.

Io. Devi, C.U. (200o). Phytosociology and Primary Production of the macrophytes in the Freshwater Ecosystems of Canchipur, Manipur. Ph.D. Thesis, Manipur University, Manipur, India.

II. Devi, C.B. (200I). Variation in species distribution and primary production of the macrophytes in Sanapat lake, Manipur. Ph.D. Thesis, Manipur University, Manipur, India.

I2. Devi, C.N. (2002). Vegetational structure and primary production of the macrophytes of Ikop lake, Manipur. Ph.D. Thesis, Manipur University, Manipur, India.

13. Devi, L.G. (2007). Studies on the Vegetational Dynamics and Primary Productivity of Awangsoipat lake, Bishnupur (Manipur). Ph.D. Thesis, Manipur University, Manipur, India.

14. Devi, S.U. (2008). Ecological analysis of the macrophytes 
in Oksoipat lake (Bishnupur) Manipur. Ph.D. Thesis, Manipur University, Manipur, India.

I5. Zotina, T.A. (2008). The biomass of macrophytes at several sites of the upper reaches of the Yenisei River. Journal of Siberian Federal University. Biology I, IO2Io8.

16. Singh, K.K., Sharma, B.M. \& Usha, K. (2010). Biomass dynamics of the macrophytic species of Kharungpat lake, Manipur, India. The Bioscan 2, 373-382.

17. Devi, T.M. (20II). Ecological studies of the macrophytes of Yenapat Lake (Bishnupur), Manipur. Ph.D. Thesis, Manipur University, Manipur, India.

I8. Devi, N.P. (2011). Species Distribution and Primary Productivity of the macrophytes of in Hidenkompat Lake (Bishnupur), Manipur. Ph.D. Thesis, Manipur University, Manipur, India.

19. Singh, K.K. \& Sharma, B.M. (2012). Ecological Productivity studies of the macrophytes in Kharungpat Lake, Manipur, Northeast India. International Journal of Geology, Earth and Environmental Sciences 2, 58-71.

20. Maqbool, C. \& Khan, A.B. (2013). Biomass and carbon content of emergent macrophytes in Lake Manasbal, Kashmir: Implications for carbon capture and sequestration. International Journal of Scientific and Research Publications 3, I-7.

2I. Tamire, G. \& Mengistou, S. (2014). Biomass and net aboveground productivity of macrophytes in relation to physico-chemical factors in the littorial zone of Lake Ziway, Ethiopia. Tropical Ecology 55, 313-326.

22. Odum, H.T. (1956). Primary Production in floating waters. Limnology and Oceanography I, I37-I44.

23. Welch, P.S. (1948). Limnological Methods. McGraw-Hill Book Company, New York, pp. I-38I.

24. Edwards, R.W. \& Owens, M. (1960). The effects of plants on river conditions. I. Summer crops and estimates of net productivity of macrophytes in a Chalk stream. Journal of Ecology 48, I5I-160.

25. Sahai, R. \& Sinha, A.B. (1976). Productivity of submerged macrophytes in polluted and non-polluted region of the eutrophic lake, Ramgarh (U.P.). In Aquatic weeds in S.E. Asia. (C.K. Varshney \& J. Rzoska, eds.), Dr. Junk Publications. The Hague, pp. I3I-I4O.

26. Shah, J.D. \& Abbas, S.G. (1979). Seasonal variation in frequency, density, biomass and rate of production of some aquatic macrophytes of the River Ganges and Bhagalpur (Bihar). Tropical Ecology 20, 127-I33.

27. Devi, S.U. \& Sharma, B.M. (2010). Variations in the biomass of the macrophytes of Oksoipat lake
(Bishnupur), Manipur, India. Ecology, Environment EG Conservation 16, 5I-55.

28. Sharma, B.M. \& Devi, N.B. (2002). Ecological assessment of macrophytes in Loktak lake, Manipur, Phytosociology. In: Ecology of Polluted waters. (A. Kumar, eds.). APH Publishing Corporation. New Delhi, pp. 869-876.

29. Devi, O.I. (1993). Distribution, primary production and nutrient status of the macrophytic communities in Waithou lake, Manipur. Ph.D. Thesis, Manipur University, Manipur, India.

30. Mishra, B.P. \& Tripathy, B.D. (2004). Distribution of macrophytes and phytosociology of Hydrilla verticillata Casp. and Lemna minor in lotic and lentic aquatic ecosystems. Ecology, Environment \&ु Conservation 1o, 37-41.

31. Ambasht, R.S. (1971). Ecosystem study of a tropical pond in relation to primary production of different vegetational zones. Hydrobiologia 12, 57-6I.

32. Crowder, A.A., Briston, J.M., King, M.R. \& Vaderkoet, S. (1977). Distribution seasonality and biomass of aquatic macrophytes in lake Opinicon. Naturaliste Canadien 104, 44I-456.

33. Kaul, V. (1977). Limnological survey of Kashmir lakes with reference to trophic status and conservation. International Journal of Ecology and Environmental Science 3, 29-44.

34. Howard-Williams, C., Davis, J. \& Vincent, W.F. (1986). Horizontal and vertical variability in the distribution of aquatic macrophytes in lake Waikaremona, New Zealand. Journal of Marine and Freshwater Research 20, 5565.

35. Vyas, L.N., Sankhla, S.K. \& Paliwal, P.P. (1989). Hydrobiological studies of Udaipur lakes. In: Perspectives in Ecology. (J.S. Singh \& B. Gopal, eds.). Jagmander Book Agency, New Delhi, pp. 389-4II.

36. Wassink, E.C. (1975). Photosynthesis and Productivity in different environments. Conclusion.. In: Photosynthesis and Productivity in different environments. (J.P. Cooper, eds.). Cambridge University Press, Cambridge, pp. 675-688.

37. Billore, S.K. \& Vyas, L.N. (1982). Distribution and Production of macrophytes in Pichhola lake, Udaipur (India). In: Wetlands Ecology and Management. (B. Gopal, R.E. Turner, R.G. Wetzel \& D.F. Whigham, eds.). National Institute of Ecology and International Scientific Publications, New Delhi, pp. 45-54.

38. Spencer, C.N. \& King, D.L. (1984). Role of fish in regulation of plant and animal communities in eutrophic ponds. Canadian Journal of Fisheries and Aquatic Sciences 4I, I85I-I855. 
39. Freedman, B. (1989). Environmental Ecology: The Ecological Effects of Pollution, Disturbances, and other Stresses. Academic Press. London, pp. I-573.

40. Forsberg, C. (1960). Subaquatic macrovegetation in Osbysjon Djursholm. Oikos II, I83-199.

4I. Whittaker, R.H. \& Likens, G.E. (1973). Primary Production. The Biosphere and Man. Human Ecology I, 357369.

42. Sculthorpe, C.D. (1967). The Biology of aquatic vascular plants. St. Martins Press, New York, pp. I-6ro.
43. Hudon, C., Lalonde, S. \& Gagnon, P. (2000). Ranking the effects of site exposure. Plant Growth form, water depth and transparency of aquatic plant biomass. Canadian Journal of Fisheries and Aquatic Sciences 57, 3I-42.

44. Devi, C.N. \& Sharma, B.M. (2006). Productive status of the macrophytes in Ikop lake, Manipur. In: Advancing Frontiers of Ecological Researches in India. (A.K. Kandya \& A. Gupta, eds.). Bishen Singh \& Mahendra Pal Singh Publication, Dehradun, India, pp. 257-270. 